\title{
PENGETAHUAN PERAWAT DALAM PENDOKUMENTASIAN ASUHAN KEPERAWATAN
}

\author{
Wanda Miftah Fatihah
}

Email : wandamiftah22@gmail.com

\begin{abstract}
ABSTRAK
Kegiatan dokumentasi keperawatan merupakan hal pokok dalam pertanggung jawaban kinerja profesi perawat, jika dokumentasi tidak lengkap maka akan berdampak pada kualitas pelayanan, kualitas pelayanan rumah sakit akan menurun. Dokumentasi dalam asuhan keperawatan sangat penting, namun kenyataannya beberapa perawat masih banyak yang kurang mengetahui pentingnya dokumentasi keperawatan yang benar.
\end{abstract}

Kata Kunci : Dokumentasi, pengetahuan perawat, rumah sakit

Nursing documentation activities are the main thing in the responsibility of the performance of the nursing profession, if the documentation is incomplete it will have an impact on the quality of service, the quality of hospital services will decrease. Documentation in nursing care is very important, but in reality some nurses still know little about the importance of correct nursing documentation.

Keywords : Documentation, nursing knowledge, hospital 
Latar Belakang

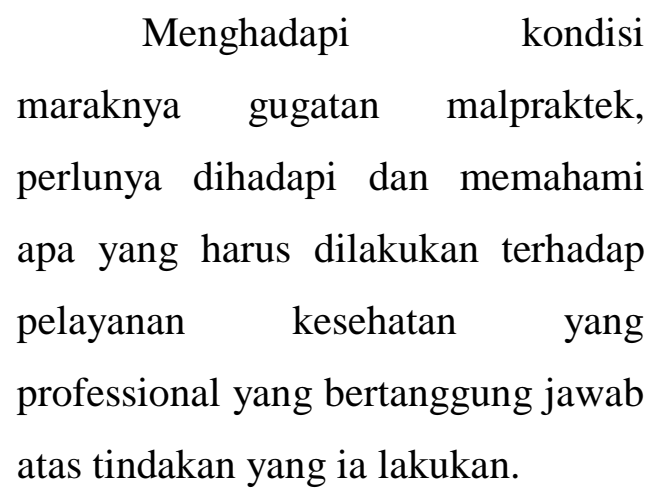

Dokumentasi merupakan bukti pelaporan dan pencatatan yang dilakukan perawat dalam catatan yang berguna untuk kepentingan asuhan klien,dan perawat dalam memberikan pelayanan kesehatan dengan dasar data yang benar, lengkap dan akurat.

Jika pelaporan dan pencatatan rekam medis pasien tidak lengkap maka akan mengakibatkan informasi dalam rekam medis menjadi tidak akurat,dan tidak tepat. Selain itu, ketidaklengkapan pencatatan dokumentasi rekam medis dapat mempengaruhi terhadap kegunaan rekam medis seperti administrasi, hukum, pendidikan, keuangan, dan penelitian.

Pendokumentasian asuhan
keperawatan merupakan sesuatu
yang berguna untuk rumah sakit
dalam indikator pelayanan mutu,

sumber data penelitian, dan peningkatan standar akreditasi.

Sebagai perawat yang memiliki peran dalam melakukan proses pendokumentasian asuhan keperawatan di rekam medis, diperlukan pengetahuan yang dimiliki perawat. Perawat diharapkan untuk memahami dan menerapkan pendokumentasian status kesehatan pasien.

\section{Metode}

Metode yang digunakan dalam penulisan kajian ini dengan menganalisis, eksplorasi beberapa tesis, jurnal, text book, maupun ebook yang relevan dan berfokus pada pengetahuan perawat dalam pendokumentasian asuhan keperawatan. E-journal yang digunakan pada kajian ini didapatkan dengan memuat google scholar dan pubmed dengan memasukan kata kunci " nursing documentation”, “ documentation patient in nursing"

\section{Hasil}

Berdasarkan hasil referensi yang didapatkan mengenai pengetahuan perawat dalam pengetahuan asuhan keperawatan, 
yang telah dilakukan dari beberapa sumber, kajian, atau penulisan ini di dapatkan hasil yaitu pengetahuan perawat sangat penting dalam memahami dan menerapkan dokumentasi keperawatan pada klien untuk meningkatkan mempertanggung jawabkan kinerja dan meningkatkan kualitas rumah sakit.

\section{Pembahasan}

Salah satu aspek yang berpengaruh terhadap peningkatan mutu pelayanan dirumah sakit ialah pengelolaan sistem rekam medis, rekam medis sangat penting karna merupakan sebuah sumber informasi penyelanggaraan pelayanan di rumah sakit.

Sistem rekam medis yang sebagaimana disebutkan pada Peraturan Menteri Kesehatan Republik Indonesia Nomor 269/MENKES/PER/III/2008 tentang Rekam Medis pada pasal 1 ayat 1 , adalah berkas yang berisikan tentang dokumen dan catatan mengenai pemeriksaan pasien, identitas pasien, pengobatan, tindakan dan pelayanan lain yang telah diberikan kepada pasien.
Pendokumentasian asuhan keperawatan dipengaruhi oleh beberapa faktor yakni latar belakang lama masa kerja, pendidikan yang pernah dilalui, keterampilan, pengetahuan yang dimiliki, dan psikologis dan adanya motivasi.

pelayanan keperawatan profesional yang berdasarkan dengan ilmu pengetahuan mempunyai proses keperawatan yakni suatu asuhan keperawatan sebagai metode ilmiah penyelesaian masalah keperawatan pasien untuk meningkatkan dampak atau efek yang ditimbulkan pasien yang harus didokumentasikan

Pendokumentasian asuhan keperawatan harus dilakukan sebagai tanggung dalam profesi sebagai perawat yang professional. Perawat menuliskan catatan atau dokumentasi keperawatan asuhan keperawatan pada dokumen rekam medis yang ada di rumah sakit. Pendokumentasian ini merupakan bukti tertulis mengenai pelaksanaan asuhan keperawatan terhadap tindakan keperawatan yang sudah dilakukan, pasien terhadap tindakan medis, dan bagaimana reaksi pasien pada penyakitnya. 
Namun,

nyatanya

dokumentasi rekam medis masih jarang dilakukan perawat karna kurangnya pengetahuan mengenai pentingnya pencatatan, dan kadang pencatatan yang dilakukan tidak selalu sesuai dengan tepat dan lengkap sebagaimana semestinya.

Perawat mungkin lupa mendokumentasikan catatan dengan lengkap karna kesibukannya, perawat yang terlalu sibuk dan lupa mendokumentasikan obat atau tindakan asuhan keperawatan yang sudah dilakukan dan diberikan pada pasien.

$$
\text { Apabila kegiatan }
$$

pendokumentasian keperawatan tidak diterapkan dengan lengkap dan akurat maka tindakan keperawatan yang telah dilakukan dengan benar akan sulit untuk dibuktikan.

Berikut merupakan ciri dokumentasi asuhan keperawatan yang baik :

1. Pendokumentasian dilakukan dengan tepat waktu (time liness)

2. Pendokumentasian bersifat gampang dibaca ( legibility)
3. Pendokumentasian dilakukan dengan lengkap

complements)

4. Dokumentasi dilakukan sesuai dengan fakta yang akurat ( factual basic)

Dokumentasi keperawatan memiliki beberapa komponen. Berikut merupakan komponen dokumentasi perawatan, antara lain :

a. Model dokumentasi SOR (SourceOriented-Record)

Pendokumentasian yang bersumber dari pencatatan. Staff kesehatan seperti perawat, dokter, ahli gizi, dan dokter yang membuat observasi dan pencatatannya sendiri dan melakukan kegiatan satu sama lain tanpa tergantung. Catatan yang dilakukan masing-masing kemudian akan dikumpulkan menjadi satu.

b. Model dokumentasi POR (Problem-Oriented-Record)

Pada model dokumentasi POR ini dilakukan dokumentasi berdasarkan masalah yang di alami klien dalam memberikan layakan kepada klien.

c. Model dokumentasi CBE (Chariry By Exeption) 
Pada

model

pendokumentasian keperawatan ini

dilakukan pencatatan dari hasil atau penemuan secara naratif yang

menyimpan keadaan normal.

d. Model dokumentasi PIE (Problem intervention and Evaluation)

Pada pendokumentasian PIE ini dilakukan saat klien masuk dan diikuti dengan pelaksanaan pengkajian sistem tubuh setiap perawat melakukan pergantian jaga (8 jam)

e. Dokumentasi Keperawatan dengan kode ( Coded Nursing Documentation/CND)

Pendokumentasian CND ini dilakukan dengan sistem komputer yang mana pendokumentasian asuhan keperawatan yang di catat menggunakan kode saja. Jadi, pada pendokumentasian CND ini di uraikan penyakit yang dialami klien bahkan dievaluasi apa yang akan dicapai klien tersebut.

Definisi pengetahuan (knowledge) menurut Webster's New World Dictionary of the American Language ialah persepsi tentang sesuatu yang jelas dan tentu, semua yang telah dirasakan dan diterima oleh otak, serta Pentingnya pengetahuan mengenai dokumentasi asuhan keperawatan pada perawat sebagai dasar saat mengambil keputusan untuk melakukan dokumentasi asuhan keperawatan yang benar dan baik.

\section{Penutup}

\section{Kesimpulan}

Dari hasil kajian yang saya kerjakan mengenai pentingnya pengetahuan perawat dalam pendokumentasian asuhan keperawatan yaitu perlunya staff keperawatan untuk melakukan pendokumentasian asuhan keperawatan yang telah dilakukan pada pasien. Catatan dalam pendokumentasian dalam rekam medis, yang digunakan juga untuk mengevaluasi tindakan terhadap pasien dan pendokumentasian pada rekam medis merupakan bukti legal yang tertulis. Pendokumentasian ini akan berdampak pada kinerja perawat dan meningkatnya kualitas rumah sakit. 


\section{Daftar Pustaka}

Dalami. E. (2011). Dokumentasi Keperawatan Dengan Kurikulum Berbasis Kompetensi. Jakarta : Trans Info Media.

Daskein, R., Moyle, W., \& Creedy, D. (2009). Aged-care nurses' knowledge of nursing documentation: an Australian perspective. Journal of Clinical Nursing, 18(14), 2087-2095.

Fitri. N.T. Korompis, G. E. C. Kaunang, W. P. J. (2019). FaktorFaktor Yang Berhubungan Dengan Pendokumentasian Asuhan Keperawatan Di Rumah Sakit Daerah Kota Tidore Kepulauan. Jurnal KESMAS. 8(3). 60-68.

Gunawan. (2016). Faktor-Faktor Yang Memengaruhi Penerimaan Perawat Melaksanakan Pendokumentasian Asuhan Keperawatan. Jurnal Pendidikan. 1(10). 1926-1934.

Lee, S., Jeon, M. Y., \& Kim, E. O. (2019). Implementation of Structured Documentation and Standard Nursing Statements.
CIN: Computers, Informatics, Nursing, 37(5), 266-275.

Muryani. Pertiwiwati, E. Setiawan, H. (2019). Kualitas Pendokumentasian Asuhan Keperawatan Di Ruang Rawat Inap. Nerspedia. 2(1). 27-32.

Putra Aryata P.I. (2012). Analisis Penerapan Standar Asuhan Keperawatan di Ruang Rawat Inap Rumah Sakit Umum Provinsi Sulawesi Tenggara. Yogyakarta. UGM. Tesis Universitas Gajah Mada 2012.

Rohimah, Nikmatur. (2010). Integrasi proses keperawatan dalam pembelajaran klinik keperawatan. One to One teaching and feed Back. The Indonesia jurnal of Health Science, 1(1).

Rutami, \& Setiawan. (2012).Pelaksanaan Proses Pengkajian Keperawatan di Ruang Rawat Inap RSUP H. Adam Malik Medan. Jurnal USU. 1 (2), 52-54.

Simamora, R. H., Purba, J. M., Bukit, E. K., \& Nurbaiti, N. (2019). Penguatan Peran Perawat Dalam Pelaksanaan Asuhan 
Keperawatan Melalui Pelatihan

Layanan Prima. JPPM (Jurnal

Pengabdian Dan Pemberdayaan

Masyarakat), 3(1), 25-31.

Siswanto, et al., (2013). Faktor-

faktor yang Berhubungan dengan

Kelengkapan Pendokumentasian.

Jurnal Keperawatan Indonesia. 16 (2). 77-84.

Supratti. (2016). Pendokumentasian Standar Asuhan Keperawatan Di Rumah Sakit Umum Daerah Mamuju, Indonesia. 2(1), 44-51.

Törnvall, E., Wahren, L. K., \& Wilhelmsson, S. (2009). Advancing Nursing

Documentation-An Intervention Study Using Patients With Leg Ulcer As An Example. International Journal of Medical Informatics, 78(9), 605-617. 
